\title{
Strategi Pengembangan Usaha Pembuatan Tepung Tapioka Pada Kelompok Tani Basamtasa Kecamatan Insana Barat
}

Goni Gundo Naibano ${ }^{\mathrm{a}}$, Adelina Norawati Hutapea ${ }^{\mathrm{b}}$

${ }^{a}$ Fakultas Pertanian, Universitas Timor, Kefamenanu, Indonesia

${ }^{b}$ Fakultas Pertanian, Universitas Timor, Kefamenanu, Indonesia

\section{Article Info}

Article history:

Received 27 Mei 2016

Received in revised form 4 Juni 2016

Accepted 25 Juli 2016

\section{Keywords:}

Strategi Pengembangan Usaha

Tepung Tapioka

Basamtasa

Insana Barat

\section{Abstrak}

Penelitian ini di lakukan di Kecamatan Insana Barat, tujuan dari penelitian ini untuk mengetahui bagaimana gambaran umum pengelolahan tepung dan strategi pengembangan industri tepung tapioka. Metode analisis data yang digunakan adalah analisis data deskriptif kualitatif dan analisis SWOT. Pembuatan tepung tapioka yang dilakukan dikelompok tani basamtasa semi modern dan relatif mudah mulai dari pengadaan bahan baku, pemotongan ubi, pengeringan, pengilingan, pengayakan sampai pemasaran. Berdasarkan grafik analisis SWOT titik kordinat 0,88 dan 1,24 berada pada kuadran I (Agresif) yang berarti posisi ini menandakan bahwa situasi dalam usaha kelompok tani menguntungkan. Sesuai hasil matriks SWOT di peroleh 4 strategi utama yang dilakukan berdasarkan matriks SWOT diantara:1) Strateg SO : Kekuatan yang ada memiliki lahan sendiri, ketersediaan bahan baku, kebersamaan yang dimiliki kelompok, dan komitmen dalam berusaha produksi tapioka untuk memperoleh peluang dukungan PEMDA dan permintaan pasar yang ada. 2) Strategi WO : meningkatkan SDM untuk memproduksi tapioka, belum ada surat ijin, dan promosi harus segara diatasi pelayanan yang lebih baik dari pemerintah daerah untuk lebih membuka peluang permintaan pasar, yang lebih tinggi. 3) Strategi ST : Kekuatan yang ada komitmen dalam berusaha, dengan ketersedian bahan baku lebih diperkuat untuk mengantisipasi ancaman persaingan produk sejenis dari luar TTU. 4) Strate gi WT : Meningkatkan SDM untuk dapat bersaing dengan pengusaha sejenis dari luar TTU dan meningkatkan promosi untuk jangkuan pemasaran yang lebih luas. C2016 dipublikasikan oleh Agrimor.

\section{Pendahuluan}

Salah satu sektor industri yang bertahan dalam masa krisis ekonomi adalah agroindustri seperti industri kecil pengolahan ubi kayu (tapioka). Industri keci tapioka berkembang karena didukung selain tersedianya bahan baku, juga sarana prasarana produksi seperti mesin giling, tempat pengeringan dan tempa pencucian. Selain itu, pekerja sebagai pengolah ubi kayu menjadi tepung tapioka merupakan pekerjaan yang sudah turun temurun.

Untuk dapat menghasilkan idustri yang mempunyai keunggulan kompetitif, menurut Baharsyah (1991) pengembangan agroidustri haruslah memperhatikan keunggulan komperatif, yang berarti didasarkan kepada ketersedian sumber daya domestik dan menggunakan teknologi maju.

Tepung tapioka memiliki prospek pengembangan yang bagus untuk dikembangkan, pertama dilihat dari ketersediaan ubi kayu yang berlimpah sehingga kemungkinan kelangkaan produk dapat dihindari karena tidak tergantung dari impor. Kedua yaitu harga tepung tapioka relatif lebih murah dibanding dengan harga tepung terigu maupun tepung beras, sehingga biaya pembuatan produk dapat lebih rendah. Dan yang ketiga adalah pasar lokalnya sangat prospektif karena begitu banyak industri makanan yang menggunakan bahan baku tepung. Dengan demikian lahirnya teknologi produksi tepung singkong modifikasi (tapioka) akan bermanfaat bagi industri pengolahan makanan nasional sebagai diversifikasi pangan berbahan local, selain itu diharapkan membuka peluang bisnis besar yang bisa meningkatkan ekonom lokal. Oleh karena itu, untuk memenuhi kecukupan gizi dan ketersediaan bahan- bahan pangan tersebut. Salah satu cara dengan mengembangkan budaya makan / konsumsi makanan pokok berbasis tepung non beras, yang memiliki manfaat tak kalah positif dari beras sebagai sumber karbohidrat.

Berdasarkan data BPS Kabupaten Timor Tengah Utara dalam angka tahun 2014, jumlah produksi ubi kayu di Kabupaten Timor Tengah Utara pada empat tahun terakhir mengalami peningkatan. Pada tahun 2010 dengan hasil produks ubi kayu sebanyak 55.502 ton, pada tahun 2011 dengan hasil produksi ubi kayu sebanyak 98.841 ton, pada 2012 mengalami penurunan hasil produksi ubi kayu sebanyak 92.224 ton, dan pada tahun 2013 produksi ubi kayu sebanyak 100.115 ton, (BPS TTU, 2014).

Kecamatan Insana Barat yang berada di Kabupaten Timor Tengah Utara memiliki berbagai industri pengelolahan pangan skala rumah tangga maupun skala industri kecil. Kelompok tani Basam Tasa dibentuk pada tahun 2008 dengan produksi pertama yaitu tortila, pada tahun 2011 kelompok tani Basam Tasa mengembangkan usahanya dengan mengolah ubi kayu menjadi tepung tapioka yag hasil produksinya hanya menjadi promosi awal. Pada tahun 2012 hasil produksi tapioka baru dipasarkan dan mendapat keuntungan. Kelompok in dibentuk dengan jumlah anggota kelompok 16 orang, peralatan pengolahan diberikan kepada anggota kelompok dan digunakan bersama- sama dalam memproduksi tepung tapioka. Kemudian hasil dari produksi dibagikan ke anggota kelompok agar memperlancar dan mempercepat pemasaran Keuntungan dari hasil jualan dimasukan ke yuran kelompok.

Tepung tapioka merupakan salah satu agroindustri yang terdapat di kecamatan Insana Barat. Hal ini karena terdapat sentral usaha industri tepung tapioka dan di dukung oleh lahan yang potensial dengan luas lahan 10 ha Produksi tepung tapioka dari tahun ke tahun mengalami perubahan. Ini terbukt dari hasil produksi tiga tahun terakhir, pada tahun 2012 kelompok tani Basam Tasa memproduksi tapioka sebanyak $775 \mathrm{~kg}$, pada tahun 2013 kelompok tani Basam Tasa memproduksi tapioka sebanyak $125 \mathrm{~kg}$, dan pada tahun 2014 kelompok tani Basam Tasa memproduksi tapioka sebanyak $597 \mathrm{~kg}$. Dari data diatas terlihat adanya penurunan hasil produksi pada tahun 2013, disebabkan karena pada tahun 2013 kelompok tani Basam Tasa sempat terhenti dalam kurun waktu 6 bulan. Maka hal ini terbukti pada tahun 2013 mengalami penurunan hasil produksi tepung tapioka. Kelompok tani Basam Tasa mengolah tepung tapioka yang memiliki nilai ekonomis dengan harga yang relatif lebih murah yakni $\mathrm{Rp}$ 5.000 per kg. Hal ini karena kelompok Tani Basam Tasa sudah mampu mengembangkan tepung tapioka namun sistem pemasaran tepung tersebut belum begitu luas dan masih dalam tahap promosi, sehingga jalur pemasaran tepung tapioka masih di pasar lokal di kabupaten TTU saja. Sistem pemasaran tepung tapioka disalurkan langsung ke tangan konsumen, dikarenakan lebih cepat dan lebih mengutungkan dibandingkan hasil tepung tapioka disalurkan ke minimarket

Masalah yang selalu dihadapi kelempok tani Basam Tasa dalam pengembangan agroindustri tapioka yang sangat besar belum mampu diwujudkan secara berdaya guna dan hasil guna. Hal ini disebabkan karena kerbatasan sumber daya permodalan, rendah sumber daya manusia, hambatan teknologi, dan rendahnya efektifitas kelembagaan yang belum mampu melaksanakan fungsi-fungsi yang strategis. Kendala lain pada kelompok tani Basam Tasa pada sistem pemasaran, antara lain belum adanya bantuan pemasaran produk dari pemerintah, masih terbatasnya pengetahuan tentang manajemen agribisnis dan agroindustri, masih kurangnya keberanian dalam mengambil resiko usaha serta persaingan dengan industri lain yang skala menengah dan besar yang di kecamatan insana barat.

Untuk meningkatkan hasil produksi tapioka dibutuhkan upaya terobosan baru yang prospektif agar usaha agroindustri tapioka tetap dapat berkembang dan memperoleh keuntungan secara ekonomis. Upaya meningkatkan produksi usaha agroindustri memerlukan pengetahuan dan ketrampilan serta dukungan bahan lokal yang berkesinambungan. Melihat potensi agroindustri tapioka di Kecamatan Insana Barat, maka perlu untuk mengoptimalkan lebih jauh lagi akan peranan dari agroindustri tapioka yang merupakan salah satu sektor yang harus dikembangkan. Oleh karena itu pengembangan agroindustri tapioka menjadi peluang dalam usaha dan harus di sesuaikan dengan permasalahan agroindustri yang bersangkutan. Strategi pengembangan akan berpengaruh dalam menjaga daya saing atau eksistensi usaha dan mengatasi masalah-maslah yang ada pada usah agroindustri tapioka.

\section{Metode}

Penelitian dilakukan pada bulan Maret-Mei 2016. Penentuan sampe dilakukan secara purposive sampling (sengaja) pada kelompok Basamtasa dengan pertimbangan bahwa ketua kelompok saja yang di wawancarai. Jenis data yang digunakan dalam penelitian ini adalah data primer dan data sekunder Metode analisis data yang digunakan adalah 1) Analisis Deskriptif Kualitatif sesuai petunjuk Nazir (1988) untuk mengetahui gambaran umum strategi pengembangan usaha pembuatan tepung tapioka; 2) Analisis SWOT untuk mengidentifikasi faktor internal dan eksternal yang menjadi kekuatan, kelemahan, peluang dan ancaman dalam pengembangan usaha pembuatan tepung tapioka sesuai petunjuk Rangkuti (2005)

\section{Hasil dan Pembahasan}

\subsection{Proses Pembuatan Tepung Tapioka}

Proses pembuatan dimulai dari tahap pengupasan/pencucian, tahap pemotongan ubi, tahap pengeringan, penggilingan dan pengayakan, kemudian tahap pengemasan dan pemasaran.

\subsection{Analisis SWOT}

Perumusan strategi dapat dilakukan dengan baik setelah diketahui unsur yang termasuk lingkungan internal dan eksternal usaha tepung tapioka. Lingkungan internal menggambarkan kuantitas dan kualitas yang dimiliki, sehingga dapat diperkirakan Kuatan (Strengths), Kelemahan (Weaknes), sedangkan lingkungan eksternal dapat menggambarkan adanya peluang (Opportunity) dan Ancaman (Threats). Kekuatan meliputi mempunyai lahan 
sendiri, komitmen dalam berusaha, kebersamaan kelompok, ketersediaan bahan baku. Kelemahan meliputi kualitas SDM, keterbatasan modal, kebebasan belum sesuai standar, belum ada surat ijin, promosi. Peluang meliputi dukungan pemda, kebijakan diverifikasi, permintaan pasar, harga terjangkau. Ancaman meliputi persaingan produk sejenis dari luar TTU, jangkuan pemasaran belum luas, konsumen beralih ke produk lain.

Dari faktor strategi internal (kekuatan dan kelemahan) dan faktor eksternal (peluang dan ancaman) yang sudah diketahui, tahap selanjutnya adalah pengumpulan data. Model yang digunakan adalah matriks faktor strategi internal ( IFAS) dan faktor strategi eksternal (EFAS) pada Tabel 1.

Tabel 1. Matriks Evaluasi Faktor Strategi Internal (IFAS)

\begin{tabular}{llll}
\hline \multicolumn{1}{c}{ Faktor internal } & Ranting & Bobot & Skor \\
\hline Kekuatan & & & \\
\hline 1. Mempunyai lahan sendiri & 4 & 0,29 & 1,14 \\
2. Komitmen dalam berusaha & 4 & 0,29 & 1,14 \\
3. Kebersamaan kelompok & 3 & 0,21 & 0,64 \\
4. Ketersedian bahan baku & 3 & 0,21 & 0,64 \\
\hline Total skor Kekuatan & 14 & 1,00 & 3,57 \\
\hline Kelemahan & & & \\
\hline 1. Kualitas SDM & 3 & 0,23 & 0,69 \\
2. Keterbatasan modal & 2 & 0,15 & 0,31 \\
3. Kemasan belum sesuai standar & 2 & 0,15 & 0,31 \\
4. Belum ada surat ijin & 3 & 0,23 & 0,69 \\
5. Promosi & 3 & 0,23 & 0,69 \\
\hline Total skor Kelemahan & 13 & 1,00 & 2,69 \\
\hline
\end{tabular}

Sumber: Data Primer Diolah, 2016

Berdasarkan hasil penentuan skor (ranting $\mathrm{x}$ bobot) untuk faktor internal kekuatan (strenght) pada Tabel 1. yang memiliki rating tertinggi (4) adalah 1)Mempunyai lahan sendiri dalam mengelola tepung tapioka dengan luas lahan 10 ha. 2).Komitmen dalam berusaha yakni selalu berusaha memproduksi. Berdasarkan hasil penentuan skor (ranting $\mathrm{x}$ bobot ) untuk faktor kekuatan (strenght ) pada tabel di atas yang memiliki ranting terendah (3) adalah 1). kebersamaan kelompok : semua anggota kelompok tani selalu mengambil bagian dalam memproduksi tepung tapioka. 2). ketersediaan bahan baku: dikarenakan kelompok tani memiliki lahan produksi ubi kayu sendiri.

Berdasarkan hasil penentuan skor (ranting x bobot) untuk faktor internal kelemahan (Weaknes) pada Tabel 1. yang memiliki rating tertinggi (3) adalah 1). kualitas SDM. 2).Belum memiliki surat ijin. 3). Promosi. Berdasarkan hasil penentuan skor (ranting x bobot ) untuk faktor kekuatan (Weaknes) pada tabel di atas yang memiliki ranting terendah (2) adalah 1). Keterbatasan Modal. 2)Kemasan belum ada.

Hasil identifikasi faktor-faktor ekternal merupakan peluang dan ancaman rating dan pembobotan dipindahkan ke tabel matriks EFAS untuk untuk diberi skoring ( rating $\mathrm{x}$ bobot) pada Tabel 2.

Tabel 2. Matriks Evaluasi Faktor Eksternal (EFAS)

\begin{tabular}{|c|c|c|c|}
\hline Faktor Eksternal & Ranting & Bobot & Skor \\
\hline \multicolumn{4}{|l|}{ Peluang } \\
\hline 1. Dukungan PEMDA & 4 & 0,29 & 1,14 \\
\hline 2. Kebijakan diversifikasi & 4 & 0,29 & 1,14 \\
\hline 3. Permintaan pasar & 3 & 0,21 & 0,64 \\
\hline 4. Harga terjangku & 3 & 0,21 & 0,64 \\
\hline Total Skor Peluang & 14 & 1,00 & 3,57 \\
\hline \multicolumn{4}{|l|}{ Ancaman } \\
\hline $\begin{array}{l}\text { 1. Persaingan produk sejenis dari } \\
\text { luar TTU }\end{array}$ & 2 & 0,33 & 0,67 \\
\hline $\begin{array}{l}\text { 2. Jangkauan pemasaran belum } \\
\text { luas }\end{array}$ & 3 & 0,50 & 1,50 \\
\hline $\begin{array}{l}\text { 3. Konsumen beralih ke produk } \\
\text { lain }\end{array}$ & 1 & 0,17 & 0,17 \\
\hline Total Skor Ancaman & 6 & 1,00 & 2,33 \\
\hline
\end{tabular}

Dari hasil penentuan skor (rating $\mathrm{x}$ bobot) peluang (opportunity) dalam faktor eksternal pada Tabel 2. yang memiliki rating tertinggi (4) Sangat berpeluang adalah 1)Dukungan PEMDA 2). kebijakan diversifikasi. Dari hasil penentuan skor (rating $\mathrm{x}$ bobot) peluang (opportunity) dalam faktor eksternal pada tabel 2 di atas yang memiliki rating terendah (3) adalah 1). permintaan pasar. 2). Harga terjangkau.

Dari hasil penentuan skor (rating $\mathrm{x}$ bobot) ancaman (threats) dalam faktor eksternal pada Tabel 2. yang memiliki rating tertinggi (3 dan 2) adalah 1). Jangkuan Pemasaran belum luas. 2). Persaiangan produk sejenis dari luar TTU. Dari hasil penentuan skor (rating $\mathrm{x}$ bobot) peluang (opportunity) dalam faktor eksternal pada tabel 2 di atas yang memiliki rating terendah (1) adalah 1). Konsumen akan beralih ke produk yang karena produk yang dibuat tidak sesuai yang diinginkan

Tabel 3. menunjukan bahwa selisih faktor strategis internal (kekuatan dan kelemahan) adalah sebesar 0,88 . Yang artinya pengaruh kekuatan lebih besar dibandingkan dengan pengaruh kelemahan terhadap pengembangan usaha tapioka di Kelompok Tani Basam Tasa Kecamatan Insana Barat Kabupaten
Timor Tengah Utara. Sedangkan selisih faktor eksternal ( peluang dan ancaman) adalah sebesar 1,24. Artinya pengaruh peluang lebih besar dibandingkan pengaruh ancaman terhadap pengembangan usaha tapioka di kelompok Tani Basam Tasa Kecamatan Insana Barat Kabupaten Timor Tengah Utara.

Tabel 3. Penggabungan Matreiks Evaluasi Faktor Strategi Internal (IFAS) dan Matriks Evaluasi Faktor Strategi Eksternal (EFAS)

\begin{tabular}{|c|c|c|c|}
\hline Faktor internal & Ranting & Bobot & Skor \\
\hline \multicolumn{4}{|l|}{ Kekuatan } \\
\hline 1. mempunyai lahan sendri & 4 & 0,29 & 1,14 \\
\hline 2.komitmen dalam berusaha & 4 & 0,29 & 1,14 \\
\hline 3.kebersamaan kelompok & 3 & 0,21 & 0,64 \\
\hline 4.ketersediaan bahan baku & 3 & 0,21 & 0,64 \\
\hline Total skor Kekuatan & 14 & 1,00 & 3,57 \\
\hline \multicolumn{4}{|l|}{ Kelemahan } \\
\hline 1.Kualitas SDM & 3 & 0,23 & 0,69 \\
\hline 2.keterbatasan modal & 2 & 0,15 & 0,31 \\
\hline 3.kemasan belum sesuai standar & 2 & 0,15 & 0,31 \\
\hline 4.belum ada surat ijin & 3 & 0,23 & 0,69 \\
\hline 5.Promosi & 3 & 0,23 & 0,69 \\
\hline Total skor Kelemahan & 13 & 1,00 & 2,69 \\
\hline selisih (kekuatan-kelemahan) & & & 0,88 \\
\hline Faktor Eksternal & Ranting & Bobot & Skor \\
\hline \multicolumn{4}{|l|}{ Peluang } \\
\hline 1.dukungan PEMDA & 4 & 0,29 & 1,14 \\
\hline 2. kebijakan diversifikasi & 4 & 0,29 & 1,14 \\
\hline 3.Permintaan pasar & 3 & 0,21 & 0,64 \\
\hline 4.Harga terjangkau & 3 & 0,21 & 0,64 \\
\hline Total Skor Peluang & 14 & 1,00 & 3,57 \\
\hline \multicolumn{4}{|l|}{ Ancaman } \\
\hline $\begin{array}{l}\text { 1.persaingan produk sejenis dari } \\
\text { luar TTU }\end{array}$ & 2 & 0,33 & 0,67 \\
\hline 2.jangkuan pemasaran belum luas & 3 & 0,50 & 1,50 \\
\hline 3.konsumen beralih ke produk lain & 1 & 0,17 & 0,17 \\
\hline Total Skor Ancaman & 6 & 1,00 & 2,33 \\
\hline selisih (peluang-ancaman) & & & 1,24 \\
\hline
\end{tabular}

Posisi pengembangan usaha tapioka pada kelompok tani basam tasa di daerah penelitian berada dikuadran I yang artinya posisi ini menandakan bahwa situasi dalam usaha kelompok tani menguntungkan. Setelah menyusun hasil grafik di atas maka tahap selanjutnya , perlu dilakukan analisis dengan menyusun faktor- faktor strategi dalam matriks SWOT.

\begin{tabular}{|c|c|c|}
\hline EFI & $\begin{array}{l}\text { Strength(S) } \\
\text { S1.Mempunyai lahan sendiri } \\
\text { S2.Komitmen dalam } \\
\text { berusaha } \\
\text { S3.Kebersamaan kelompok } \\
\text { S4.ketersedian bahan baku }\end{array}$ & $\begin{array}{l}\text { Weakneses (W) } \\
\text { W1. Kualitas SDM } \\
\text { W2.Modal yang } \\
\text { terbatas } \\
\text { W3.Kemasan belum } \\
\text { seuai standar } \\
\text { W4.Belum ada surat } \\
\text { ijin } \\
\text { W5. Promosi }\end{array}$ \\
\hline $\begin{array}{l}\text { Opportunities }(\mathrm{O}) \\
\text { 1. Dukungan pemda } \\
\text { 2. Kebijakan diversifikasi } \\
\text { 3. Permintaan Pasar } \\
\text { 4. Harga terjangkau }\end{array}$ & $\begin{array}{l}\text { Strategi SO } \\
\text { Kekuatan yang ada berupa } \\
\text { mempunyai lahan sendiri, } \\
\text { komitmen dalam berushan, } \\
\text { kebersamaan kelompok,dan } \\
\text { ketersediaan bahan baku } \\
\text { yang dimiliki kelompok tani } \\
\text { memperoleh peluang } \\
\text { dukungan dari pemerintah } \\
\text { untuk mengeluarkan } \\
\text { kebijakan diversifikasi untuk } \\
\text { meningkatkan permintaan } \\
\text { pasar yang luas. }\end{array}$ & $\begin{array}{l}\text { Strategi WO } \\
\text { Kelemahan yang ada } \\
\text { kualitas SDM, modal } \\
\text { yang terbatas, kemasan } \\
\text { belum sesuai standar, } \\
\text { belum memiliki surat } \\
\text { ijin dan kurangnya } \\
\text { promosi hendaknya } \\
\text { segera diatasi dengan } \\
\text { pelayanan yang lebih } \\
\text { baik dari pemerintah } \\
\text { untuk lebih membuka } \\
\text { peluang permintaan } \\
\text { pasar, }\end{array}$ \\
\hline $\begin{array}{l}\text { Threats(T) } \\
\text { T1.Persaingan produk } \\
\text { sejenis dari luar TTU } \\
\text { T2.Jangkuan pemasaran } \\
\text { belum luas } \\
\text { T3.konsumen beralih ke } \\
\text { yang produk lain }\end{array}$ & $\begin{array}{l}\text { Strategi ST } \\
\text { Kekuatan yang ada } \\
\text { dikelompok tani berupa } \\
\text { komitmen dalam berusaha, } \\
\text { kebersamaan yang ada } \\
\text { dikelompok tani dan bahan } \\
\text { baku yang tersedia lebih } \\
\text { diperkuat untuk } \\
\text { mengantisipasi ancaman } \\
\text { persaingan produk sejenis } \\
\text { dari luar TTU dan } \\
\text { meningkatkan jangkuan } \\
\text { pemasaran yang belum luas. }\end{array}$ & $\begin{array}{l}\text { Strategi WT } \\
\text { Meningkatkan SDM } \\
\text { untuk dapat bersaing } \\
\text { dengan pengusaha } \\
\text { sejenis dari luar TTU } \\
\text { dan meningkatkan } \\
\text { promosi untuk jangkuan } \\
\text { pemasaran yang lebih } \\
\text { luas }\end{array}$ \\
\hline
\end{tabular}


Berdasarkan Tabel 4. pada Matriks SWOT diatas maka didapatkan 4 langkah strategi yaitu sebagai berikut :

\section{Strategi S-O}

Strategi ini didapatkan dengan memanfaatkan dan memaksimalkan kekuatan yang dimiliki oleh kelompok tani basamtasa untuk mengambil atau memanfaatkan peluang yang ada. Berdasarkan hasil analisis diperoleh beberapa strategi berikut : Kekuatan yang ada berupa memiliki lahan sendiri, komitmen dalam berushan, kebersamaan kelompok,dan ketersediaan bahan baku yang dimiliki kelompok tani untuk memperoleh peluang dukungan dari pemerintah untuk mengeluarkan kebijakan diversifikasi dan meningkatkan permintaan pasar yang luas.

2. Strategi S-T

Strategi ini didapatkan dengan memaksimalkan kekuatan yang dimiliki kelompok tani basamtasa dalam mengantisipasi ancaman yang ada. Berdasarkan hasil analisis diperoleh beberapa strategi berikut : Kekuatan yang ada dikelompok tani berupa komitmen dalam berusaha, kebersamaan yang ada dikelompok tani dan bahan baku yang tersedia lebih diperkuat untuk mengantisipasi ancaman persaingan produk sejenis dari luar TTU dan meningkatkan jangkuan pemasaran yang belum luas.

3. Strategi W-O

Strategi ini didapatkan dengan usaha menekan atau meminimalisasi kelemahan yang dimiliki kelompok tani basamtasa untuk memanfaatkan peluang yang ada saat ini. Berdasarkan hasil analisis diperoleh beberapa strategi berikut :Kelemahan yang ada kualitas SDM, modal yang terbatas, kemasan belum sesuai standar, belum memiliki surat ijin dan kurangnya promosi hendaknya segera diatasi dengan pelayanan yang lebih baik dari pemerintah untuk lebih membuka peluang permintaan pasar.

4. Strategi W-T

Strategi ini didapatkan melalui usaha meminimalisasi kelemahan yang dimiliki kelompok basamtasa untuk mengantisipasi ancaman atau untuk menghadapi kemungkinan ancaman yang ada dari lingkungan eksternal. Berdasarkan hasil analisis diperoleh beberapa strategi berikut : Meningkatkan SDM untuk dapat bersaing dengan pengusaha sejenis dari luar TTU dan meningkatkan promosi untuk jangkuan pemasaran yang lebih luas.

\section{Simpulan}

Modal awal yang digunakan dalam memulai usaha tepung tapioka pada kelompok tani basamtasa adalah modal sendiri. Proses produksi tepung tapioka yang dilakukan dikelompok tani basamtasa semi modern dan relatif mudah mulai dari pengadaan bahan baku, pengecilan ukuran, pengeringan, pengilingan, pengayakan sampai pemasaran. Berdasarkan graifik analisis SWOT titik kordinat 0,88 dan 1,24 baerada pada kuadran I (Agresif) yang berarti posisi ini menandakan bahwa situasi dalam usaha kelompok tani menguntungkan. Perusahan tersebut memiliki peluang dan kekuatan sehingga dapat memanfaatkan peluang yang ada. Sesuai hasil matriks SWOT di peroleh 4 strategi utama yang dilakukan berdasarkan matriks SWOT diantara:1) Strategi SO : Kekuatan yang ada memiliki lahan sendiri, ketersediaan bahan baku, kebersamaan yang dimiliki kelompok, dan komitmen dalam berusaha produksi tapioka untuk memperoleh peluang dukungan PEMDA dan permintaan pasar yang ada. 2) Strategi WO : meningkatkan SDM untuk memproduksi tapioka, belum ada surat ijin, dan promosi harus segara diatasi pelayanan yang lebih baik dari pemerintah daerah untuk lebih membuka peluang permintaan pasar, yang lebih tinggi. 3). Strategi ST : Kekuatan yang ada komitmen dalam berusaha, dengan ketersedian bahan baku lebih diperkuat untuk mengantisipasi ancaman persaingan produk sejenis dari luar TTU. 4). Strategi WT : Meningkatkan SDM untuk dapat bersaing dengan pengusaha sejenis dari luar TTU dan meningkatkan promosi untuk jangkuan pemasaran yang lebih luas.

\section{Pustaka}

Baharsyah, S. 1991. Peranan dan prospek agribisnis dalam pembangunan di sector pertanian. Sambutan Menteri Muda Pertanian tentang Agroindustri dan Agribisnis, Departemen Pertanian

Badan Pusat Statistik Kabupaten TTU. 2014. Timor Tengah Utara dalam Angka. Kefamenanu

Nazir, M. 1988. Metode Penelitian, Ghalia Indonesia: Jakarta

Rangkuti,. 2005. Analisis SWOT Teknik Membedah Kasus Bisnis. Gramedia Pustaka Utama. Jakarta. 